\title{
Cytoprotective effects of garlic on spermatozoa quality and fertilizing ability of
} extended porcine semen

Sokunbi, O. A., *Alaba, O., Ogunwumiju, B., Eboh, S. and Iruo, T. Animal Physiology and Bioclimatology Laboratory, Department of Animal Science, University of Ibadan, Ibadan, Nigeria. Corresponding author: femialaba@gmail.com; +2347054634435

\section{Abstract}

Fertilizing potential of spermatozoa is pivotal for successful artificial insemination. Preservation of boar semen is associated with the production of reactive oxygen species which leads to decline of spermatozoa quality and decrease in fertilizing ability. The study aimed at investigating the effects of Ethanolic Allium sativum Extracts (EASE) as a cytoprotective agent on the quality and fertilizing potential of spermatozoa in extended boar semen. Semen was collected and aliquot portions were divided into 60 sample bottles comprising of five treatments with replicates. T1 served as the control (Beltsville Thawing Solution (BTS) + semen) in ratio 1:3 semen-extender, while other treatments T2 to T5 contained semen-extender at the same ratio, but supplemented with EASE at varying concentrations of 50, 75, 100 and $125 \mu \mathrm{g} / \mathrm{L}$ respectively stored at $17^{\circ} \mathrm{C}$ and were evaluated at 0, 24, 48 and 72 hours for pH, normal spermatozoa (NS) (\%), liveability (\%), acrosome integrity (AI) (\%) in a completely randomized design. Data obtained were subjected to descriptive statistics and analysed using one way ANOVA and means were separated using Duncan Multiple Range Test. Treated semen samples $(75,100$ and $125 \mu \mathrm{g} / \mathrm{L})$ gave superior $(P<0.05)$ liveability than control, up to 72 hours. Similar $(P>0.05)$ mean values were observed for NS from all treatments except $50 \mu \mathrm{g} / \mathrm{L}$ at 24 hours. At 72 hours, treated samples $(75,100$ and $125 \mu \mathrm{g} / L)$ gave superior $(P<0.05)$ NS. Significant differences $(P<0.05)$ in mean values for $\mathrm{pH}$ were observed among treatments through the extension period. However, all values were within accepted range for quality semen. Acrosome integrity were similar $(P>0.05)$ among treatments from 0 to 72 hours, but reduced $(P<0.05)$. Results suggest that the supplementation of BTS with EASE $125 \mu \mathrm{g} / \mathrm{L}$, gave better cytoprotection to the spermatozoa compared to the control.

Keywords: Ethanolic Allium sativum Extracts (EASE), semen quality, spermatozoa fertilizing potential, porcine semen.

\section{Les Effets cytoprotecteurs de l'ail sur la qualité des spermatozoïdes et la capacité de fertilisation du sperme de porc prolongé}

Sokunbi, O. A., *Alaba, O., Ogunwumiju, B., Eboh, S. et Iruo, T. Animal Physiology and Bioclimatology Laboratory,

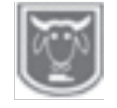

\section{Résumé} Department of Animal Science, University of Ibadan, Ibadan, Nigeria.

Corresponding author: femialaba@gmail.com; +2347054634435

L'ablitédes spermatozoïdes de fertiliserest essentiel pour une insémination artificielle réussie. La conservation de la semence de l'our est associée à la production d'espèces réactives de l'oxygène, ce qui entraîne un déclin de la qualité des spermatozoïdes et une diminution de la capacité de fertilisation. L'étude visait à étudier les effets des extraits éthanoliques d'Allium sativum (EEAS) en tant qu'agent cytoprotecteur sur la qualité et le potentiel fertilisant des spermatozoïdes dans le sperme de sanglier étendu. Le sperme a été collecté et les portions aliquotes ont été divisées en 60 bouteilles d'échantillons comprenant cinq traitements avec des répliques. T1 a servi de contrôle (BeltsvilleThawing Solution (BTS) 
+ sperme) dans un rapport 1: 3 sperme-extenseur, tandis que d'autres traitements T2 à T5 contenaient sperme-extenseur au même rapport, mais complété avec EEAS à des concentrations variables de 50,75, 100 et $125 \mu \mathrm{g} / \mathrm{L}$ respectivement conservés à $17^{\circ} \mathrm{C}$ et ont été évalués à 0, 24, 48 et 72 heures pour le pH, les spermatozoïdes normaux (SN) (\%), l'habitabilité (\%), l'intégrité de l'acrosome (IA) (\%) dans une conception complètement aléatoire. Les données obtenues ont été soumises à des statistiques descriptives et analysées en utilisant une méthode ANOVA et les moyennes ont été séparées en utilisant le test Duncan Multiple Range. Les échantillons de sperme traités (75, 100 et $125 \mu \mathrm{g} / \mathrm{L})$ ont donné une habitabilité supérieure $(P<0,05)$ à celle des témoins, jusqu'à 72 heures. Des valeurs moyennes similaires $(P>0,05)$ ont été observées pour le $S N$ pour tous les traitements, sauf 50 $\mu \mathrm{g} / \mathrm{L}$ à 24 heures. A 72 heures, les échantillons traités $(75,100$ et $125 \mathrm{ug} / \mathrm{L})$ ont donné une SN supérieure $(P<0,05)$. Des différences significatives $(P<0,05)$ dans les valeurs moyennes du pH ont été observées entre les traitements pendant la période d'extension. Cependant, toutes les valeurs se situaient dans la plage acceptée pour le sperme de qualité. L'intégrité des acrosomes était similaire $(P>0,05)$ parmi les traitements de 0 à 72 heures, mais réduite $(P<0,05)$. Les résultats suggèrent que la supplémentation en BTS avec EEAS $125 \mu \mathrm{g} / \mathrm{L}, \mathrm{a}$ donné une meilleure cytoprotection des spermatozoïdes par rapport au témoin.

Mots clés : Extraits éthanoliques d'Allium sativum (EEAS), qualité du sperme, potentiel fertilisant des spermatozoïdes,sperme de porc.

\section{Introduction}

In Nigeria swine production plays a vital role in food security, poverty eradication, and employment generation (Nwanta et al., 2011). Artificial Insemination (AI) is a reproductive technique which offers significant benefits including genetic selection, prolonged fertility even during unfavourable times of the year; cycle based production, more efficient breeding programs and improved health monitory. When compared with natural mating, $\mathrm{AI}$ is a very useful tool to introduce superior genes into sow herds, with a minimal risk of disease (Maes et al., 2008). The fertilizing potential of a semen dose is inherently linked to the quality of the spermatozoa itself (Tsakmakidis et al., 2010). The quality of boar semen stored in a liquid state is influenced by the type of extender and storage time (Johnson et al., 2000). Research has shown that short and mediumterm extenders (up to 5 days), as early as on the second day of storage, spermatozoa motility and the percentage of normal spermatozoa morphology decrease and DNA disintegration increases, which makes them unsuitable for insemination (Wrona et al., 2009; Klimont et al., 2015) owing to generation of reactive oxygen species (ROS) as intermediate in mitochondrial metabolic pathways leading to oxidative stress and reduced fertility. Inclusion of antioxidants can reduce oxidative damage caused to semen by scavenging harmful molecules. The supplementation of a cryopreservation extender with antioxidant has been shown to provide a cytoprotective effect on mammalian spermatozoa quality (Amrit et al., 2011). The fertility enhancing capacity of plant extract has been reported in numerous studies. Plant derived antioxidants have been getting major focus due to their lower cytotoxicity and are considered to be better than synthetic antioxidants (Ibrahim et al., 2014). Akunna et al. (2013) reported that paramount attention is been shifted from synthetic products to natural plant products.

Garlic (Allium sativum) and its constituents prepared by various means have been shown to have diverse biological activities, including anti-carcinogenic, anti- 


\section{Sokunbi, Alaba, Ogunwumiju, Eboh and Iruo}

atherosclerotic, anti-thrombotic, antimicrobial, anti-oxidative, antiinflammatory and various other biological actions. Potential antioxidant properties of garlic are as a result of presence of phenolic and flavonoids fractions (Miller et al., 2000). Allicin is the most predominant of these bioactive compounds, representing approximately $70 \%$ of the thiosulfinates in garlic (Han et al., 1995).

The cytoprotective potential of Allium sativum ethanolic extract on semen quality and its spermatozoa fertilizing ability in extended porcine semen was investigated in this study.

\section{Materials and methods Experimental location}

Semen collection was carried out at the Piggery Unit of the Teaching and Research Farm, University of Ibadan $\left(7^{\circ} 20^{\prime} \mathrm{N}, 3^{\circ} 50^{\prime} \mathrm{E}\right.$; 200 - 300 above sea level), while the analyses of semen were carried out at the Animal Physiology and Bioclimatology Laboratories of the Department of Animal Science of the same institution.

\section{Management of the boar and semen collection}

Semen was collected from a mature boar with a proven semen quality and fertility for this study. The boar was kept in an intensively managed, clean and well ventilated pen. Feed and clean water were supplied ad libitum. Semen was collected into a boar semen collection cup; lined with a disposable plastic bag and covered with a disposable milk filter. The gel-fraction was separated from the sperm-rich fraction by the milk filter covering the semen collection cup. The gloved-hand technique/method was used to collect semen from the boar. Before the ejaculate collection, the boar was thoroughly washed to eliminate urine and other materials that could lead to semen contamination during collection. As the boar initiates extension of the penis on a standing heat sow, the end of the penis, which is cork screw shaped was held strongly by gloved hand. Collection procedure started with strong force to the coiled part of the penis by hand. Collection continued until the boar dismounted.

Preparation of extract from garlic (Allium sativum L.) bulb

Fresh garlic bulbs were purchased from a location, about $2 \mathrm{~km}$ from the study site. The fresh garlic bulbs were peeled and $150 \mathrm{~g}$ was weighed out and fully chopped to increase its surface area, then oven dried at $45^{\circ} \mathrm{C}$, for seven days and later ground into a powdery form using a ceramic mortar. Ethanol (absolute) was used for the extraction using a Sohxlet extractor. Rotary evaporator was further used to obtain a concentrated garlic extracts. Afterwards, the garlic extract was dried up in an incubator at $45{ }^{\circ} \mathrm{C}$ for 24 hours. The garlic extract was recovered and reconstituted using dimethyl sulfoxide (DMSO) and stored $\left(4{ }^{\circ} \mathrm{C}\right)$ for subsequent use.

\section{Preparation of semen extender}

Prior to semen collection from the boar, a Beltsville Thawing Solution $\left(\mathrm{BTS}^{\circledR}\right)$ Extender was prepared. The collected ejaculate was mixed thoroughly but gently in a swirling motion with the extender (in a ratio of 1:3) at a differential temperature of not more than $1{ }^{\circ} \mathrm{C}$.

Table 1: Chemical composition of beltsville thawing solution (BTS) extender

\begin{tabular}{lc}
\hline Composition & Quantity $(\mathbf{g} / \mathbf{L})$ \\
\hline Glucose & 37.00 \\
Sodium citrate & 6.00 \\
Potassium chloride & 0.75 \\
EDTA & 1.25 \\
Sodium bicarbonate & 1.25 \\
Penicillin & 1.10 \\
Streptomycin & 1.10 \\
\hline \multicolumn{2}{c}{ Source: Johnson (2000); EDTA: Ethylene diamine tetra acetate } \\
\multicolumn{2}{c}{$\mathbf{5 0}$}
\end{tabular}


Semen collection, processing, extension and evaluation

Semen samples collected were immediately evaluated for mass activity, progressive motility, liveability, percentage normal spermatozoa, $\mathrm{pH}$ and the temperature was checked 15 minutes after collection. The volume of collected ejaculate was estimated by weighing on a top loader balance. Semen aliquots were diluted in each of experimental extenders (treatments). Diluted semen was preserved in a thermo regulated fridge at $17^{\circ} \mathrm{C}$ and evaluated for liveability, normal spermatozoa, $\mathrm{pH}$ and acrosome integrity at $0,24,48$ and 72 hours.

\section{Semen quality evaluation}

\section{Liveability}

A drop of the extended semen was placed on a warm microscope slide with a micropipette, and a drop of eosin-nigrosin stain was added, smeared, immediately airdried, and viewed under the microscope at magnification of X400. The proportions of live (eosin-impermeable) and dead (eosinpermeable) spermatozoa in a sample was assessed on the basis of 100 cells counted and expressed in \%.

\section{Normal spermatozoa}

A drop of extended semen sample was dropped on a glass slide, a drop of eosinnigrosin stain was added and mixed gently and smeared on a slide with the edge of another clean slide, air dried and viewed under the microscope at magnification of X400. From each smear a total of 100 spermatozoa examined. All spermatozoa with intact head, mid-piece and tail were considered normal, tallied and expressed in $\%$.

\section{pHmeasurement}

The $\mathrm{pH}$ of the extended semen treatments was measured using a calibrated digital $\mathrm{pH}$ meter (Mettler Toledo IP67 ${ }^{\circledR}$ ). The unit was calibrated using a 3-point calibration procedure utilizing buffers with $\mathrm{pH}$ of 4.0 , 7.0 and 9.0.

\section{Spermatozoa fertilizing potential assessment}

Parameters evaluated for spermatozoa fertilizing potential is; acrosome integrity. Acrosome integrity

Ejaculate smears of all samples were prepared for confirmation of acrosome integrity condition utilizing eosin-nigrosin stain. All the slides were assessed under oil immersion at X1000 magnification using a bright field microscope. A total of one hundred spermatozoa per slide were assessed, and normal acrosomes (spermatozoa without apical shifts) were expressed as percentages.

\section{Experimental treatment and design}

Aliquot portions of diluted semen were allotted to five treatments with three replicates per treatment in a completely randomized design (CRD). Evaluations of semen quality and spermatozoa fertilizing potential were carried out at time intervals of 0, 24, 48 and 72 hours.

\section{Treatment description}

Treatment 1: Semen+ Beltsville Thawing Solution $\left(\mathrm{BTS}^{\circledR}\right)$

Treatment 2: $\quad$ Semen+ BTS $+50 \mu \mathrm{g} / \mathrm{L}$ Ethanolic Allium sativum Extract(EASE)

Treatment 3: Semen + BTS $+75 \mu \mathrm{g} / \mathrm{L}$ EASE

Treatment 4: $\quad$ Semen + BTS $+100 \mu \mathrm{g} / \mathrm{L}$ EASE

Treatment 5: $\quad$ Semen + BTS $+125 \mu \mathrm{g} / \mathrm{L}$ EASE

\section{Statistical analysis}

Data obtained were analyzed using oneway analysis of variance (ANOVA) procedure of SAS (2011) and means were compared using Duncan's multiple range test of the same software.

\section{Results and discussion Effect of EASE on liveability of extended boar semen}

The effect of EASE on the spermatozoa liveability in extended Boar semen 
refrigerated at $17^{\circ} \mathrm{C}$ is presented in Figures 1 and 2. There were significant differences $(\mathrm{P}<0.05)$ observed across all the treatments during the period of storage (preservation). At 0 hour, T3, T4, T5 and T2 were statistically similar, but significantly different $(\mathrm{P}<0.05)$ from $\mathrm{T} 1(85.00 \%)$. At 72 hour, mean values obtained for liveability in T2, T3, T4 and T5 were significantly $(\mathrm{P}<0.05)$ higher than $\mathrm{T} 1(87.67 \%)$, which gave the lowest value and T4 (100.00\%) gave the highest mean value.
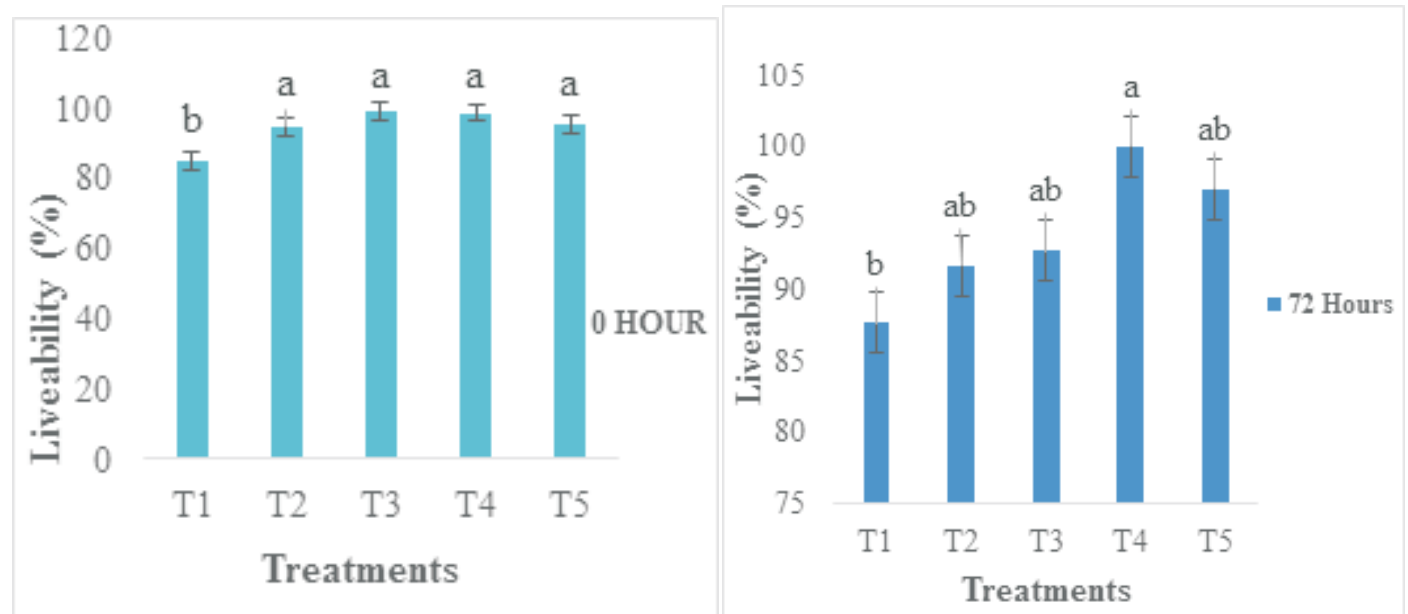

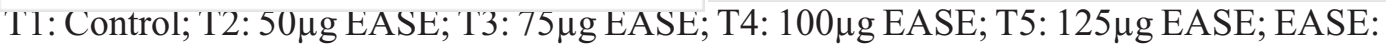
Ethanolic Allium sativum Extract

a,b: bars with different superscripts are significantly different $(\mathrm{P}<0.05)$

Figures 1 and 2: Effect of EASE on liveability of extended boar semen at 0 hour and 72 hours respectively

There were fluctuations in the mean values obtained for spermatozoa liveability across the treatments. Spermatozoa liveability was lower in T1, but all the mean values obtained falls within the normal range of quality semen. Cerollina et al. (2000) reported that the inclusion of an antioxidant into the diluent prevent the significant decline in viability of sperm cells, and this could explain the observation of high mean values of live cells, compared to dead cells. The result from this study indicates that spermatozoa liveability was not affected, from the onset to the end of the experiment. The results obtained fall within the range of recommended good quality spermatozoa and thus suggest that Ethanolic Allium sativum extract was able to supply exogenous antioxidant to the spermatozoa, as a cytoprotective nutrient against spermatozoa damage in the extender during liquid refrigeration at $17^{\circ} \mathrm{C}$.

\section{Effect of EASE on normal spermatozoa of extended boar semen}

Figures 3 and 4 show the mean value obtained for normal spermatozoa of extended boar semen supplemented with EASE preserved at $17^{\circ} \mathrm{C}$. At 0 hour, there were no significant different $(\mathrm{P}>0.05)$ across treatments. At 24 hours, T1 (90.00 $\%)$, T3 (89.67\%), T4 (91.00\%) and T5 $(92.00 \%)$ were statistically similar but significantly $(\mathrm{P}<0.05)$ different from $\mathrm{T} 2$ (75.00\%). Normal spermatozoa at 48 hours was significantly $(\mathrm{P}<0.05)$ different across the treatments with the highest value at T5 $(98.67 \%)$ and T3 gave the lowest value $(84.67 \%)$. At 72 hours post preservation, mean values obtained varied significantly 
$(\mathrm{P}<0.05)$ across treatments, with T3 (98.67

$\%$ ) presenting the highest mean value while the least mean value was obtained in $\mathrm{T} 1$ (85.00\%). Shipley et al., (1999) reported

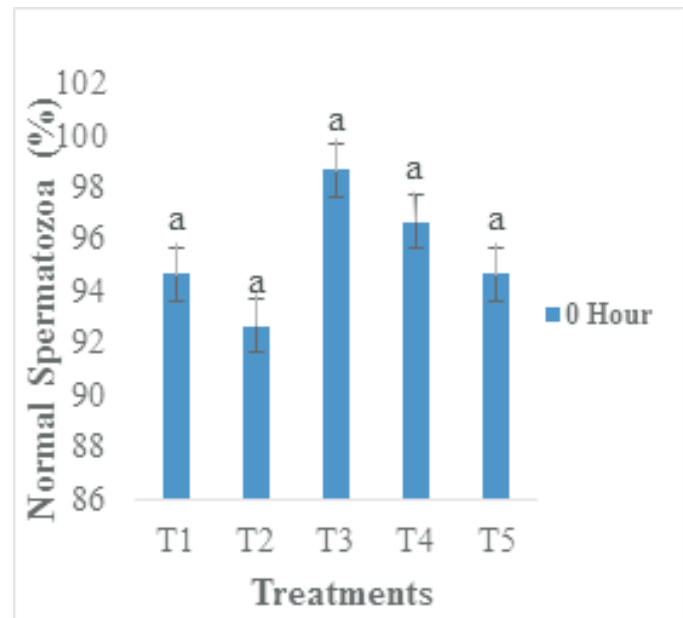

that percentage normal spermatozoa should be at least $70 \%$. With the exception of T2 at 24 hours, other mean values obtained gave abnormal spermatozoa of less than $15 \%$.

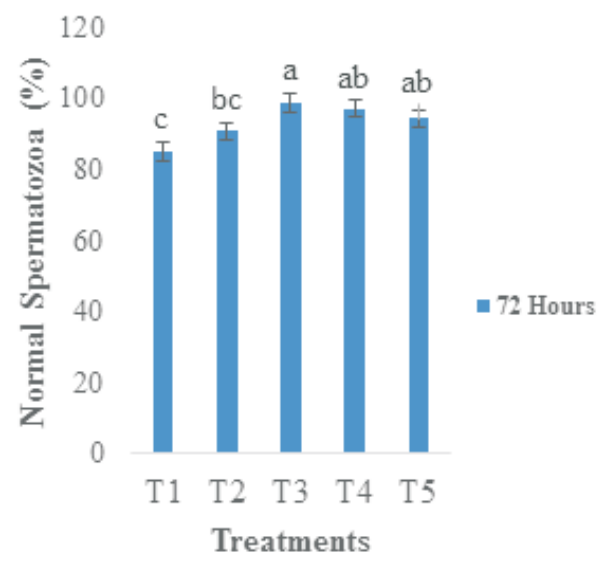

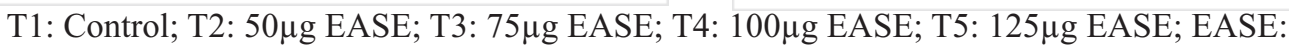

Ethanolic Allium sativum Extracts

a,b: bars with different superscripts are significantly different $(\mathrm{P}<0.05)$

Figures 3 and 4 : Effect of EASE on normal spermatozoa of extended boar semen at 0 hour and 72 hours respectively

This observation is similar with the findings of researchers (Johnson et al., 2000; John et $a l ., 2003)$ that high quality semen contains minimal number (5 to $15 \%$ ) of abnormal spermatozoa whereas low quality semen frequently contains a large number $(30 \%$ or more) of morphological abnormal spermatozoa. Morphological abnormalities of spermatozoa can have adverse effect on fertilization and embryonic development (Saake, 2008). Also, Cerolini et al. (2000) reported that inclusion of antioxidant into storage diluents prevent deterioration of boar spermatozoa quality and provide protection to the cells up to 5 days of post preservation, thereby preventing oxidative reduction in the level of major polyunsaturated fatty acid. Results observed suggest that EASE potentially maintain intact spermatozoa morphology and this could be attributed to the presence of the phenolic, allicin and other bioactive properties of garlic extract. High percentage of normal spermatozoa above $70 \%$ is also an indication of reduced microbial activities on the sperm cells.

Table 2: Effect of EASE on pH of extended boar semen at 0, 24, 48 and 72 hours

\begin{tabular}{lcccccc}
\hline Time & T1 & T2 & T3 & T4 & T5 & SEM \\
\hline 0 hour & $7.27^{\mathrm{ab}}$ & $7.26^{\mathrm{ab}}$ & $7.24^{\mathrm{b}}$ & $7.23^{\mathrm{b}}$ & $7.33^{\mathrm{a}}$ & 0.01 \\
24 hours & $7.16^{\mathrm{b}}$ & $7.30^{\mathrm{ab}}$ & $7.20^{\mathrm{b}}$ & $7.38^{\mathrm{a}}$ & $7.20^{\mathrm{b}}$ & 0.03 \\
48 hours & $7.11^{\mathrm{b}}$ & $7.15^{\mathrm{b}}$ & $7.15^{\mathrm{b}}$ & $7.21^{\mathrm{a}}$ & $7.13^{\mathrm{b}}$ & 0.01 \\
\hline 72 hours & $7.09^{\mathrm{b}}$ & $7.13^{\mathrm{a}}$ & $7.16^{\mathrm{a}}$ & $7.14^{\mathrm{a}}$ & $7.14^{\mathrm{a}}$ & 0.01 \\
\hline
\end{tabular}

a,b,c: Means along the same row with different superscripts are significantly different $\mathrm{p}(<0.05)$

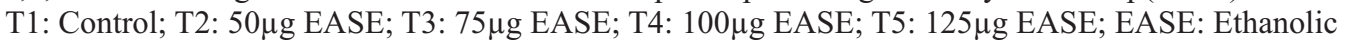
Allium sativum Extract; SEM: Standard Error Mean 
Sokunbi, Alaba, Ogunwumiju, Eboh and Iruo

Effect of EASE on pH of extended boar semen

The effect of EASE on the $\mathrm{pH}$ of extended boar semen refrigerated at $17{ }^{\circ} \mathrm{C}$ is presented in Table 2. Significant differences $(\mathrm{P}<0.05)$ occurred across the treatments during the storage periods $(0,24,48$ and 72 hours). At 0 hour, T3 (7.24) and T4 (7.23) are statistically similar, but significantly $(\mathrm{P}<0.05)$ different from other treatments, with the highest mean value obtained in T5 (7.33) and T4 (7.23) gave the least. At 24 hours, T1 (7.16) was statistically similar to T3 (7.20) and T5 (7.20), but significantly $(\mathrm{P}<0.05)$ different from other treatments. At 48 hours, T1 (7.11), T2 (7.15), T3 (7.15) and T5 (7.13) are statistically similar, but significantly $(\mathrm{P}<0.05)$ different from $\mathrm{T} 4$ (7.21), with $\mathrm{T} 4$ presenting the highest $\mathrm{pH}$ while the least $\mathrm{pH}$ was obtained in $\mathrm{T} 1 . \mathrm{pH}$ at 72 hours was significantly $(\mathrm{P}<0.05)$ highest in T3 (7.16) and the lowest $\mathrm{pH}$ mean value was obtained in $\mathrm{T} 1$ (7.09), although $\mathrm{T} 2$ (7.13), T3 (7.16), T4 (7.14) and T5 (7.14) were statistically similar, but significantly $(\mathrm{P}<0.05)$ higher than T1 (7.09). The Mean values of $\mathrm{pH}$ obtained in this study shows that, there were significant $(\mathrm{P}<0.05)$ differences across the treatments, during the period of storage (0 to 72 hours) at $17^{\circ} \mathrm{C}$. Mean values obtained ranges from 7.09 to 7.38. These values fall within the normal range which is 6.8-7.5. There was reduction in the $\mathrm{pH}$ values obtained across the treatments, though values obtained still fall within the recommended range. Intracellular $\mathrm{pH}$ reduction obviously reduced spermatozoa metabolism and increase spermatozoa survival during storage (Johnson et al., 2000). The importance of $\mathrm{pH}$ on survival of sperm cells cannot be undermined, because there are some sources of biochemical alterations on spermatozoa which include: increased concentration of solute, dehydration and changes in temperature (Johnson et al., 2000). The results obtained in this study indicate that, Ethanolic Allium sativum extracts does not have negative effects on the $\mathrm{pH}$ of extended boar semen, refrigerated at $17^{\circ} \mathrm{C}$.
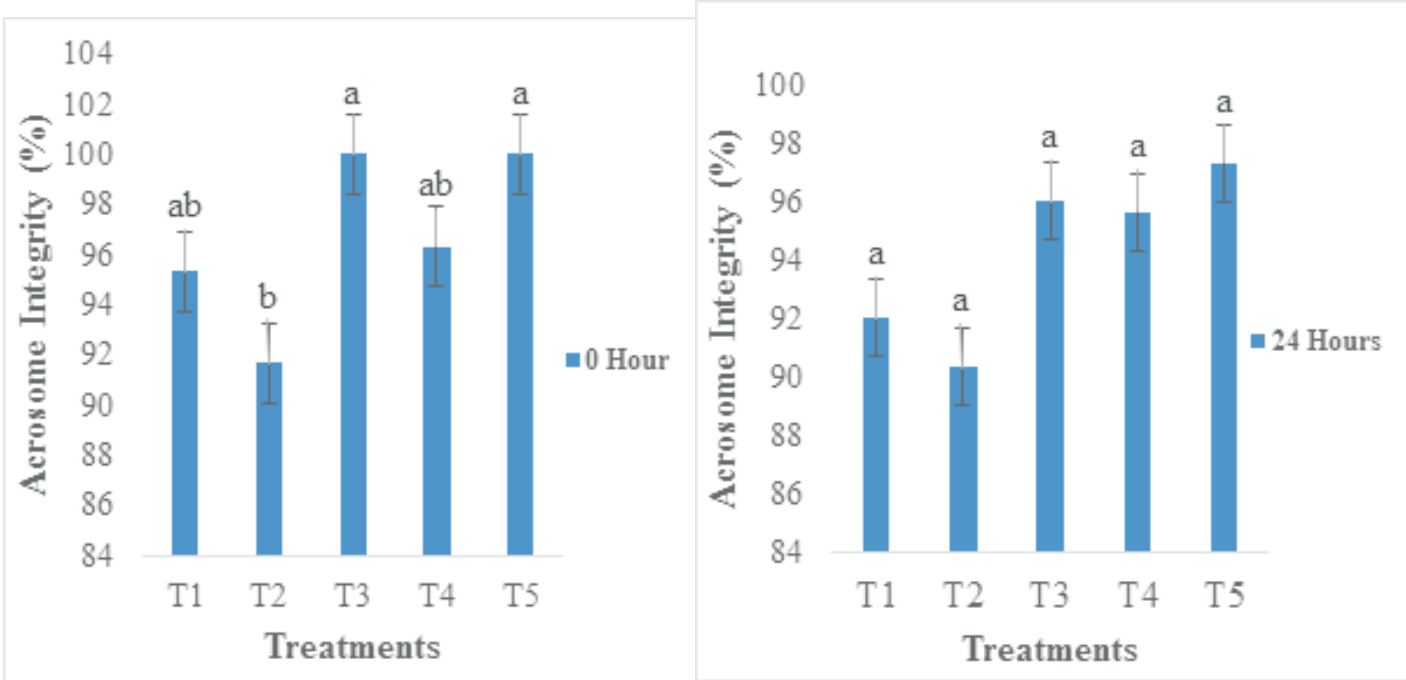

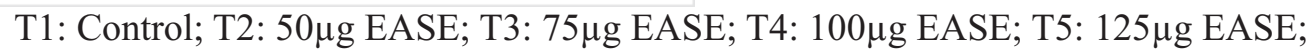
EASE: Ethanolic Allium sativum Extract a,b: bars with different superscripts are significantly different $(\mathrm{P}<0.05)$

Figures 5 and 6: Effect of EASE on acrosome integrity of extended boar semen at 0 and 24 hours respectively 
Effect of EASE on acrosome integrity of extended boar semen

Acrosome integrity of spermatozoa in extended boar semen, supplemented with EASE at $17^{\circ} \mathrm{C}$ is presented in Figures 5 and 6. Significant difference $(\mathrm{P}<0.05)$ only occurred at 0 hour. At 24 hours, 48 hours and 72 hours, mean acrosome integrity were not significantly different $(\mathrm{P}>0.05)$ across treatments. At 0 hour, mean values recorded for T3 $(100.00 \%)$ and T5 (100.00 $\%$ ) are similar but significantly different $(\mathrm{P}<0.05)$ from other treatments. Despite the insignificant differences $(\mathrm{P}>0.05)$ recorded at 24,48 and 72 hours; at 24 hours, T5 $(97.33 \%)$ presented the highest mean value and T2 (90.33\%) the least. At 48 hours, T3 $(95.67 \%)$ gave the highest mean value while T1 $(90.00 \%)$ and T2 (90.00\%) similarly presented the lowest values. At 72 hours, mean values obtained varied from T4 $(94.33 \%)$ to T1 (86.33\%). Acrosome integrity is an important parameter useful in predicting the fertilizing capacity of spermatozoa in vitro. From this study, it was observed that acrosome integrity was intact across the treatments from 0 to 72 hours of observation, except for a little fluctuation in $\mathrm{T} 4$ at 48 hours observation. This is an indication that EASE has the capacity to maintain the integrity of the acrosome. However, acrosome integrity decline with storage time at $17{ }^{\circ} \mathrm{C}$. This finding is in line with the report of Gadea $e t$ al. (2005), who stated that, reduced gluthathione could lower acrosome integrity, improving the function and fertilizing capacity of frozen boar spermatozoa. These results were in submission with the findings of Waberski et al. (2011) who reported that storage of semen for longer period causes ultrastructural, biochemical and function damage to the spermatozoa, resulting in a decline in motility, viability, fertility and impaired acrosome integrity and transport. Also, reduction in acrosome integrity will result in induced acrosome reaction of greater portion of spermatozoa before reaching the site of fertilization (Waberski et al., 2011). The significant difference $(\mathrm{P}<0.05)$ in the mean values of acrosome integrity across the treatments, with $\mathrm{T} 3$ and T5 recording the highest mean values corroborates with the finding of Kommisrud et al. (2002) and Frydrychova et al. (2010) who reported that the storage time significantly influenced motility and acrosome integrity. This finding indicates that EASE inclusion at $75 \mu \mathrm{g}$ and $125 \mu \mathrm{g}$ competes favourably in preservation of the acrosome integrity better than a conventional extender(T1).

\section{Conclusion}

The study suggested that spermatozoa quality and fertilizing potential can be maintained up to 48 hours, BTS extender supplemented with $125 \mu \mathrm{g}$ ethanolic Allium sativum extracts. The supplementation of BTS with EASE $125 \mu \mathrm{g} / \mathrm{L}$, gave better cytoprotection to the spermatozoa compared to the control. However, further research should be carried out to investigate the effects of higher concentrations of EASE, for possible extension over the 72 hours period, on semen quality and spermatozoa fertilizing potential.

\section{References}

Akunna, G. G., Saalu, L. C., Ogunlade, B., Ojewale, A. O. and Enye, L.A. 2013. Consumption of bay leaf a food spice may be a safe and effective treatment for male infertility resulting from partial ligation of the left renal vein in wistar rat: Study suggest. Am. J. Res. Commun., 1:123-142.

Amrit, K. B. and Bilaspuri, G. S. 2011. Impacts of Oxidative Stress and Antioxidants on Semen andrology research and veterinary practice. 
Theriogenology, 57: 149-179.

Cerolini, S., Maldjian A., Surai P. and Nobel. 2000 . Viability, susceptibility to peroxidation and fatty acid composition of boar semen during liquid storage. AnimReprod. Sci. 58: 99-111.

Frydrychová, S., Čeřovský, J., Lustyková, A. and Rozkot, M. 2010. Effects of long-term liquid commercial semen extender and storage time on the membrane quality of boar semen. J. Anim. Sci. 55(4):160-166.

Gadea, J., Garcia- Vazquez, F., Matas, C., Gordon, J. C., Canovas, S. 2005. Cooling and freezing of boar spermatozoa: Supplementation of the freezing media with reduced glutathione preserves sperm function. Journal of Andrology 26: 396-404.

Han, J., Lawson, L., Han, G. and Han, P. 1995. "A spectrophotometric method for quantitative determination of allicin and total garlic thiosulfinates". Analytical Biochemistry, 225(1):157-160.

Ibrahim, A. H. B., Ahmed, R. H. and Ahmed, M. R. 2014. Antioxidant effect of green tea $1 \mathrm{e} \mathrm{a} \mathrm{v}$ e $\mathrm{s}$ extract on in vitro production of sheep embryos. Pakistan J. Zool., 46: 167-175.

John, R. C., Douglas, K. M. and Karen, L. C. 2003. Animal Science: the biology, Care and production of domestic animals. McGraw Hill Higher Education. Fourth edition. Pp. 70-72.

Johnson, L. A., Weitze, K. F., Fisher, P., Maxwell and W. M. 2000. Storage of boar semen. Anim. Reprod. Sci. 62 (1-3): 143-172.

Klimont, M., Wrona, Z., Brodzki, P. and Krakowski, L. 2015. Influence of season and storage of boar semen on the degree of DNA fragmentation of sperm. Med Weter, 71: 171-175.

Kommisrud, E., Paulenz, H., Sehested, E. and Grevle, I. 2002. Influence of porcine and ejaculate Parameters on motility and acrosome integrity in liquid porcine ejaculate preserved for fivedays. ActaVeterinariaScandinavica. 43: 49-55.

Maes, D., Nauwynck, H., Rijsselaere, T. and Soom, A.V. 2008. Diseases in swine transmitted by artificial insemination : An overview. Theriogenology 70 (8) : 1337-45.

Miller, H.E., Rigelhof, F., Marquart, L., Prakash, A. and Kanfer M. 2000. Antioxidant content of whole grain breakfast cereals, fruits and vegetables. Journal of America Coll. Nutrition; 19:18.

Nwanta, J. A., Shoyinka, S. V. O., Chah, F. K., Onunkwo, J. I., Onyenwe, I. W., Eze, J. I.,Iheagwam, C. N., Njoga, E. O., Onyema, I., Ogbu, K. I., Mbegbu, E. C., Nnadozie, P. N., Ibe, E. and Oladimeji, K. 2011. Production characteristics, disease prevalence and herd-health management of pigs in Southeast Nigeria. Journ of Swine Hlth and Prod.2011; 19(6): 331-339.

Saccke, R. G. 2008. Sperm morphology: Its relevance to compensable and uncompensable traits in semen. Theriogenology. 70.473-478.

Shipley, C. 1999. Breeding soundness examination in the boar. Swine Health and Production, 31:135140.

Tsakmakidis, I. Lymberopoulos, A. and Khalifa, T. 2010. Relationship between spermquality traits and field-fertility of porcine semen. Journal of Veterinary Science, 11: 151-154. 
Cytoprotective effects of garlic on spermatozoa quality and fertilizing ability of extended porcine semen

Waberski, D., Schapmann, E., Henning, H., Riesenbeck, A. \& Brandt, $H$. 2011. Sperm chromatin structural integrity in normospermic boars is not related to semen storage and fertility after routine AI. Theriogenology, 75:337-345.
Wrona, Z., Klimont, M. and Krakowski, L. 2009. Attempt at estimating the correlation between selected parameters of boar spermatozoa movement indicators and the time of spermatozoa storage in standard conditions. Med Weter, 65: 194197.

Received: $20^{\text {th }}$ August, 2020 Accepted: $21^{s t}$ November, 2020 